\title{
MEMAKSIMALKAN PERAN TREATY OF AMITY AND COOPERATION IN SOUTHEAST ASIA 1976 (TAC) DALAM PENYELESAIAN SENGKETA DI ASEAN
}

\author{
Endah Rantau Itasari \\ Fakultas Hukum Universitas Tanjungpura Pontianak \\ E-mail : itafira@yahoo.com
}

\begin{abstract}
ABSTRAK
ASEAN merupakan organisasi regional yang beranggotakan 10 negara, tujuan dibentuknya ASEAN adalah menjaga stabilitas kawasan serta perdamaian di kawasan Asia Tenggara. Jika terjadi suatu sengketa antara anggota-anggotanya maupun dengan negara di luar anggota ASEAN dihimbau menggunakan jalan damai sesuai dengan yang tertuang dalam TAC 1976. Hal ini untuk memaksimalkan apa yang telah dituangkan di dalam TAC seperti : Saling menghormati kemedekaan, kedaulatan, dan intergritas wilayah semua bangsa; Setiap negara berhak memelihara keberadaanya dari campur tangan, subversi, kekerasan dari kekuatan luar; Tidak mencampuri urusan dalam negara lain; Menyelesaikan perbedaan pendapat dan pertikaian dengan jalan damai; serta Menolak ancaman penggunaan kekerasan. Metode yang digunakan dalam penelitian ini, yaitu kepustakaan dimana metode pengumpulan data dari buku, artikel dan bacaan lain sebagai bahasa analisis. Data akan dianalisis secara kualitatif berdasarkan teori kemudian disajikan sistematis secara deskriptif.
\end{abstract}

Kata Kunci : ASEAN, Peran Treaty Of Amity And Cooperation In Southeast Asia 1976 (TAC), Penyelesaian Sengketa Internasional.

\begin{abstract}
ASEAN is a regional organization comprising 10 countries, the establishment of ASEAN's goal is to maintain regional stability and peace in the region. In the event of a dispute between its members and with countries outside ASEAN members are encouraged to use the path of peace in accordance with the TAC set out in 1976. This is to maximize what has been stated in the TAC as : Mutual respect for the independence, sovereignty and territory integrity of all nations; Each country is entitled to maintain the existence of interference, subversion, violence from outside forces; Do not meddle in the affairs of other countries; Resolving differences opinions and disputes by peaceful means, as well as the threat of use of force Refuse. The method used in this study, the literature where the method of data collection of books, articles and other readings as language analysis. The data will be analyzed qualitatively by theory then systematically presented descriptively.
\end{abstract}

Keywords : ASEAN, the role of the Treaty of Amity and Cooperation in Southeast Asia in 1976 ( TAC) , International Dispute Settlement. 


\section{Pendahuluan}

Association of South East Asian Nations (ASEAN) diresmikan pada tanggal 8 Agustus 1967 oleh lima negara pendiri yaitu : Indonesia, Malaysia, Filipina, Thailand dan Singapura. Dengan disahkanya organisasi internasional ini, membuat di kawasan Asia Tenggara mulai menata diri untuk menjadi kawasan yang aman dan kondusif, sebelum berdirinya ASEAN banyak jalan terjal yang tengah dihadapi oleh negara pendiri pada saat itu. Masih ingat dibenak kita, negaranegara di kawasan Asia Tenggara pernah mencoba untuk mendirikan organisasi internasional seperti South East Asia Treaty Organization (SEATO) misalnya adalah organisasi regional di kawasan Asia Tenggara yang ternyata tidak saja melibatkan negara-negara Thailand, Filipina, Singapura saja, tetapi melibatkan juga negara-negara luar kawasan seperti Australia, Amerika, dan New Zealand, akan tetapi organisasi internasional tidak bertahan lama dan bubar.

Pada awal tahun 1960-an tumbuh berturut-turut dua organisasi regional yang untuk pertama kalinya dibatasi hanya untuk negara-negara Asia Tenggara dan betul-betul merupakan ide dan inisiatif dari regional Asia Tenggara sendiri, artinya bukan ide yang datang dari negara luar. Organisasi yang dimaksud adalah pertama disebut Association of Southeast Asia (selanjutnya dalam penelitian ini disingkat menjadi ASA), asosiasi ini dibentuk secara resmi pada pertemuan Bangkok tanggal 31 Juli 1961 dengan anggotanya terdiri dari tiga negara yaitu Malaysia,
Filipina, dan Thailand (Ranjit Gill, 1987).

Walaupun sebenarnya negaranegara anggota ini telah berupaya semaksimal mungkin untuk dapat memenuhi maksud dan tujuan dari organisasi ASA, akan tetapi sama seperti organisasi yang lain akhirnya ASA mengalami kegagalan. Ada dua hal yang menyebabkan ASA mengalami kegagalan yaitu (Ilien Halina, 1988) :

1) Jumlah anggota yang sangat terbatas, yang hanya terdiri dari tiga negara, Malaysia, Filipina dan Thailand. Padahal kawasan Asia Tenggara cukup luas meliputi selain tiga negara tersebut tadi juga termasuk di dalamnya negaranegara Indonesia, Singapura, Birma, Kamboja, Vietnam dan Laos.

2) Penyebab yang datangnya dari dalam organisasi itu sendiri, yang menyebabkan kegiatan ASA tidak terkontrol, kacaubalau bahkan kemudian terhenti tidak mampu lagi melaksanakan programprogramnya, hal ini disebabkan karena kurang harmonisnya hubungan di antara negara-negara anggotanya sendiri.

Dalam suasana kawasan yang tidak menguntungkan ini, Filipina mencoba mengembangkan suatu gagasan baru untuk membentuk Greater Malay Confederation. Diskusi-diskusi kemudian diadakan dari sekitar bulan Juli sampai dengan bulan Agustus 1963 di Manila. Walaupun diskusi-diskusi ini lebih banyak menekankan pada sikap dan tanggapan yang berbeda terhadap Pembentukan Federasi 
Malaysia, tetapi diskusi ini akhirnya berhasil membentuk suatu organisasi regional baru dengan nama Malaysia, Filipina, Indonesia (selanjutnya dalam penelitian ini disingkat menjadi MAPHILINDO) yang merupakan nama singkatan dari tiga negara yang menjadi anggotanya, dan organisasi ini pun mengalami kegagalan. Terlepas dari kegagalannya, sesungguhnnya bagaimana MAPHILINDO yang menekankan sifat keanggotaan yang terbatas hanya tiga negara saja, merupakan dasar bagi pemikiran selanjutnya untuk membentuk organisasi regional di kawasan Asia Tenggara. Ide-ide dasar ini telah mampu membangkitkan kembali para negarawan-negarawan yang pada gilirannya berhasil membentuk organisasi regional yang lain di kawasan ini.

Relasi antara subjek hukum internasional sangat rentan untuk terjadinya suatu sengketa. Sengketa dapat lahir dari beragam sumber potensi, seperti perbatasan, sumber daya alam, kerusakan lingkungan, perdagangan, hak asasi manusia, terorisme dan lain-lain. Pada saat sengketa tersebut timbul maka hukum internasional memainkan peran yang tidak kecil dalam penyelesaiannya (Huala Adolf, 2006).

Pada awalnya negara selalu menyelesaikan sengketa dengan cara peperangan. Hal ini dikarenakan perang masih dianggap sebagai alat diplomasi yang ampuh. Namun sering timbulnya kesadaran masyarakat internasional bahwa peperangan hanya menimbulkan kesengsaraan, maka dibuatlah ketentuan hukum positif yang menyatakan bahwa penggunaan kekerasan dalam hubungan antarnegara dilarang (Boer Mauna; 2005; 193). Kesadaran tersebut menumbuhkan keyakinan masyarakat internasional bahwa setiap sengketa harus diselesaikan secara damai.

Apa yang dikemukakan oleh Severino tersebut memang dapat dijustifikasi dengan melihat tujuan ASEAN yang terdapat dalam Deklarasi Bangkok adalah untuk (Direktorat Jenderal Kerjasama ASEAN Departemen Luar Negeri Republik Indonesia) :

1. Mempercepat pertumbuhan ekonomi, kemajuan sosial serta pengembangan kebudayaan di kawasan ini melalui usaha bersama dalam semangat kesamaan dan persahabatan untuk memperkokoh landasan sebuah masyarakat bangsabangsa Asia Tenggara yang sejahtera dan damai;

2. Meningkatkan perdamaian dan stabilitas regional dengan jalan menghormati keadilan dan tertib hukum di dalam hubungan antara negaranegara di kawasan ini serta mematuhi prinsip-prinsip Piagam Perserikatan BangsaBangsa;

3. Meningkatkan kerjasama yang aktif dan saling membantu dalam masalah-masalah yang menjadi kepentingan bersama di bidang-bidang ekonomi, sosial, teknik, ilmu pengetahuan dan administrasi;

4. Saling memberikan bantuan dalam bentuk sarana-sarana pelatihan dan penelitian dalam bidang-bidang pendidikan, 
profesi, teknik dan administrasi;

5. Bekerjasama secara lebih efektif guna meningkatkan pemanfaatan pertanian dan industri mereka, memperluas perdagangan dan pengkajian masalah-masalah komoditi internasional, memperbaiki sarana-sarana pengangkutan dan komunikasi, serta meningkatkan taraf hidup rakyat mereka;

6. Memajukan pengkajian mengenai Asia Tenggara;

7. Memelihara kerjasama yang erat dan berguna dengan berbagai organisasi internasional dan regional yang mempunyai tujuan serupa, dan untuk menjajagi segala kemungkinan untuk saling bekerjasama secara erat di antara mereka sendiri.

Prinsip utama dalam kerjasama ASEAN antara lain adalah persamaan kedudukan dalam keanggotaan (equality), tanpa mengurangi kedaulatan masingmasing negara anggota. Negaranegara anggota ASEAN sepenuhnya tetap memiliki kedaulatan ke dalam maupun ke luar (sovereignty), sedangkan musyawarah (consensus and consultation), kepentingan bersama (common interrest), dan saling membantu (solidarity) dengan semangat ASEAN merupakan ciri kerjasama ini.

Kata "dispute", menurut John G. Merrills (1;1991), mengandung pengertian pertikaian atau sengketa dimana keduanya yang dipergunakan secara bergantian. John G. Merrills memahami persengketaan sebagai terjadinya perbedaan pemahaman akan suatu keadaan atau obyek yang diikuti oleh pengklaim oleh satu pihak dan penolakan dipihak lainnya. Karena itu, sengketa internasional adalah perselisihan, yang tidak secara eksklusif melibatkan negara, dan memiliki konsekuensi pada lingkup internasional. Persoalan yang timbul adalah apa yang bisa dijadikan sebagai subjek persengketaan. Menurut John G. Merrills (529;2003) subyek dari persengketaan dapat bermacammacam, mulai dari sengketa mengenai kebijakan suatu negara sampai persoalan perbatasan. Pada umumnya metode-metode penyelesaian sengketa digolongkan dalam dua kategori yaitu cara-cara penyelesaian secara damai dan cara-cara penyelesaian secara paksa atau dengan kekerasan (A.A.S.P. Dian Saraswati,19; 2007).

Cara-cara penyelesaian sengketa secara damai dapat dilakukan apabila para pihak telah menyepakati untuk menemukan solusi yang bersahabat. J. G. Starke mengklasifikasikan metode penyelesaian sengketa-sengketa internasional secara damai atau bersahabat sebagai berikut (J. G. Starke, 646; 2007) : arbitrase, penyelesaian yudisial, negosiasi, jasa-jasa baik (good offices), mediasi, konsiliasi, penyelidikan, dan penyelesaian dibawah naungan organisasi PBB. Sementara itu, F. Sugeng Istanto (88; 1998), menyatakan bahwa penyelesaian secara damai dapat dilakukan melalui beberapa cara yakni : rujuk, penyelesaian sengketa di bawah perlindungan $\mathrm{PBB}$, arbitrasi dan peradilan.

Menurut F. Sugeng Istanto, pertikaian bersenjata atau perang 
adalah pertentangan yang disertai penggunaan kekerasan angkatan bersenjata masing-masing pihak dengan tujuan menundukkan lawan dan menetapkan persyaratan perdamaian secara sepihak. Sementara itu, menurut J. G. Starke, keseluruhan tujuan dari perang adalah untuk menaklukkan negara lawan dan untuk membebankan syarat-syarat penyelesaian di mana negara yang ditaklukkan itu tidak memiliki alternatif lain selain mematuhinya.

\section{a) Retorsi}

Menurut J. G. Starke, retorsi adalah istilah teknis untuk pembalasan dendam oleh suatu negara terhadap tindakan-tindakan tidak pantas atau tidak patut dari negara lain, balas dendam tersebut dilakukan dalam bentuk tindakantindakan sah yang tidak bersahabat di dalam konferensi negara yang kehormatannya dihina, misalnya merenggangnya hubunganhubungan diplomatik, pencabutan privilege-privilege diplomatik, atau penarikan diri dari konsensikonsensi fiskal dan bea.

Sementara itu, menurut $F$. Sugeng Istanto (100; 1998), keadaan yang membenarkan penggunaan retorsi hingga kini belum dapat secara pasti ditentukan karena pelaksanaan retorsi sangat beranekaragam. Penggunaan retorsi secara sah oleh negara anggota PBB nampak terikat oleh ketentuan Piagamnya. Pasal 2 ayat (3) Piagam PBB menetapkan bahwa anggota PBB harus menyelesaikan sengketa yang mereka hadapi dengan cara damai sehingga tidak mengganggu perdamaian dan keamanan internasional dan keadilan.

\section{b) Tindakan-Tindakan Pembalasan (Reprisal)}

Menurut Richard B. Lilich (130; 1980), pembalasan adalah metode-metode yang dipakai oleh negara-negara untuk mengupayakan diperolehnya ganti rugi dari negara-negara lain dengan melakukan tindakan-tindakan yang sifatnya pembalasan. Sementara itu F. Sugeng Istanto, memberikan definisi reprisal adalah pembalasan yang dilakukan oleh suatu negara terhadap tindakan yang melanggar hukum dari negara lawan dalam suatu sengketa. Reprisal berbeda dengan retorsi karena perbuatan retorsi hakikatnya merupakan perbuatan yang tidak melanggar hukum sedangkan perbuatan reprisal pada hakikatnya merupakan perbuatan yang melanggar hukum.

Reprisal di masa perang adalah perbuatan pembalasan antara pihak yang berperang dengan tujuan untuk memaksa pihak lawan menghentikan perbuatannya yang melanggar hukum perang. Misalnya pada tahun 1939 sampai 1940 Inggris menahan barang-barang eksport Jerman yang dimuat kapal netral sebagai pembalasan atas perbuatan tidak sah yang penenggelaman kapal dagang oleh ranjau yang dipasang angkutan laut Jerman.

\section{c) Blokade Secara Damai (Pacific Blockade)}

Pada waktu perang, blokade terhadap pelabuhan suatu negara yang terlibat perang sangat lazim dilakukan oleh angkatan laut. Namun, blokade secara damai adalah suatu tindakan yang dilakukan pada waktu damai. 
Sementara itu menurut F. Sugeng Istanto, blokade adalah suatu pengepungan wilayah, digolongkan sebagai suatu pembalasan, tindakan itu pada umumnya ditujukan untuk memaksa negara yang pelabuhannya diblokade untuk menaati permintaan ganti rugi kerugian yang diderita oleh negara yang memblokade.

Blokade secara damai untuk pertama kalinya dilakukan pada tahun 1872, karena pada tahun itu telah dilakukan sekitar 20 tindakan demikian (Walter R. Thomas, 198; 1980). Blokade secara damai pada umumnya digunakan oleh negaranegara lemah, meskipun karena itu besar kemungkinan terjadi penyalahgunaan dalam sebagaian besar kasus blokade secara damai dipakai oleh negara-negara besar yang bertindak secara bersamasama untuk tujuan kepentingan negara-negara yang bersangkutan, misalnya untuk mengakhir kerusuhan atau untuk mencegah terjadinya perang.

\section{d) Intervensi}

Perkataan intervensi kerap kali dipakai secara umum untuk menunjukkan hampir semua tindakan campur tangan oleh suatu negara dalam urusan negara lain. Menurut suatu pengertian yang lebih khusus intervensi itu terbatas pada tindakan mencampuri urusan dalam negeri atau luar negeri dari negara lain yang melanggar kemerdekaan negara itu, bukanlah satu intervensi suatu pemberian nasehat oleh suatu negara pada negara lain mengenai beberapa hal yang terletak di dalam kompetensi dari negara yang disebut kemudian untuk mengambil keputusan untuk dirinya, walaupun pada umumnya orang mengangap itu sebagai suatu intervensi. Campur tangan harus berbentuk suatu perintah, yaitu bersifat memaksakan atau ancaman kekerasan berdiri dibelakangnya (J. L. Brierly, 256; 1996), campur tangan itu hampir selalu disertai dengan bentuk atau implikasi tindakan untuk mengganggu kemerdekaan politik negara bersangkutan.

Melihat tujuan didirikannya ASEAN salah satunya adalah menjalin persaudaraan dan perdamaian diantara anggotanya, tentu hal ini hal yang sangat positif bagi organisasi regional ini. Kerangka hukum yang dapat mewujudkan itu adalah dengan adanya TAC dalam ASEAN, dalam tulisan ini akan dibahas tentang bagaimana cara untuk memaksimalkan TAC di dalam penyelesaian sengketa yang tengah dihadapi oleh para anggotanya serta diluar anggota ASEAN.

\section{Metode Penelitian}

Metode yang digunakan yaitu kepustakaan dimana metode pengumpulan data dari buku, artikel dan bacaan lain sebagai bahasa analisis. Data akan dianalisis secara kualitatif berdasarkan teori kemudian disajikan sistematis secara deskriptif.

\section{Hasil Penelitian dan Pembahasan}

ASEAN hanya merupakan sebuah asosiasi yang longgar, terbukti dengan tidak ada satu pun kesepakatan yang mengikat secara hukum diantara anggotanya selama kurang lebih sembilan tahun sejak terbentuknya ASEAN. Instrumen yang mengikat secara hukum 
pertama kali di ASEAN baru tercipta pada saat Konferensi Tingkat Tinggi ASEAN (KTT ASEAN) yang dilaksanakan di Bali pada tahun 1976, yaitu dengan disahkannya Treaty of Amity and Cooperation in South East Asia (TAC) yang telah diratifikasi oleh seluruh anggota ASEAN. Perihal yang mendasari lahirnya TAC tersebut adalah perbedaan atau perselisihan kepentingan diantara anggota yang mulai mucul ke permukaan harus dapat diatur secara rasional, efektif, dan prosedur yang memadai untuk menghindari dampak yang akan membahayakan kerjasama antarnegara anggota.

Dalam TAC tersebut kemudian diatur mengenai tujuan dan prinsipprinsip dasar dalam hubungan persahabatan dan kerjasama sesama negara anggota ASEAN. Mekanisme penyelesaian sengketa secara damai juga diadopsi dalam perjanjian tersebut. Dengan terbentuknya perjanjian tersebut diharapkan setiap perselisihan yang terjadi antara negara-negara anggota ASEAN dapat diselesaikan dalam kerangka TAC. Untuk melengkapi TAC maka telah disusun aturan dan prosedur (Rules and Procedure of High Council of the Treaty of Amity and Cooperation in South East Asia) pada tanggal 23 Juli 2001 di Hanoi, Vietnam. Dinamika baik internal maupun eksternal di ASEAN pada akhirnya telah membuat para pemimpin ASEAN bekerja untuk memperkuat organisasi guna menghadapi tantangan yang akan dihadapi dikemudian hari.

Preambul pada Deklarasi Bangkok memuat tujuan ASEAN yaitu meletakkan dasar atau fondasi yang kokoh untuk memajukan kerja sama regional, memperkuat stabilitas ekonomi, dan sosial serta memelihara perdamaian dan keamanan di kawasan Asia Tenggara (Faustinus Andrea; 2006; hlm. 183). Termasuk dalam tujuan tersebut adalah keinginan menyelesaikan sengketa di antara anggotanya secara damai tanpa menggunakan cara-cara kekerasan atau perang.

Salah satu instrumen penting dalam upaya mewujudkan dan menciptakan stabilitas politik dan keamanan di kawasan Asia Tenggara adalah the Treaty of Amity and Cooperation in Southeast Asia 1976 (TAC). Pada dasarnya prinsipprinsip yang terkandung di dalam TAC juga tercermin di dalam Piagam PBB antara lain prinsip "noninterference" (non-intervensi) dan penggunaan cara-cara damai dalam menyelesaikan sengketa tanpa menggunakan kekerasan yang timbul diantara negara-negara penandatangan TAC.

Sementara itu, Second protocol amending the Treaty of Amity and Cooperation in Southeast Asia 1998 (Protokol ke-2 amandemen TAC) yang ditandatangani para Menteri Luar Negeri ASEAN dan Papua New Guinea di Manila, 25 Juli 1998 menjadi titik awal perluasan TAC ke luar ASEAN. Upaya ASEAN untuk mempertahankan perdamaian dan stabilitas regional mengalami kemajuan pesat pada bulan Oktober 2003 dengan aksesi yang dilakukan oleh Pemerintah China dan India terhadap TAC pada KTT ASEAN ke-9 di Bali pada tahun 2003. Pemerintah Jepang dan Pakistan mengaksesi TAC pada tanggal 2 Juli 2004 saat AMM ke-37 di Jakarta. 
Sedangkan Pemerintah Rusia dan Korea Selatan mengaksesi pada Pertemuan Tingkat Menteri (PTM) ASEAN-Rusia dan PTM ASEAN Korsel pada bulan Nopember 2004 di Vientiane, Laos. Selandia Baru dan Mongolia pada AMM ke-38 mengaksesi TAC pada bulan Juli 2005 di Vientiane. Australia mengaksesi TAC pada bulan Desember 2005 di Kuala Lumpur sebelum penyelenggaraan KTT ASEAN ke-11.

Pada KTT ASEAN yang ke-12, Pemerintah Perancis dan Timor Leste mengaksesi TAC. Aksesi Perancis ke dalam TAC merupakan pengakuan penting salah satu negara Uni Eropa (UE) terhadap eksistensi ASEAN dan pentingnya pengembangan kerjasama dengan ASEAN. UE juga telah menyatakan niatnya untuk mengaksesi TAC yang menandakan kemajuan ASEAN sebagai organisasi regional yang signifikan, khususnya bagi perkembangan kerjasama kedua kawasan. Proses lebih lanjut menyangkut aksesi ini masih terus berkembang. Aksesi Pemerintah China, Rusia, dan Perancis yang merupakan negara anggota tetap Dewan Keamanan PBB menandakan dukungan yang signifikan terhadap TAC sebagai suatu tata tertib (code of conduct) dalam menjalankan hubungan antar negara di dalam dan luar kawasan ASEAN. ASEAN terus mendorong negara-negara lain di luar kawasan untuk mengaksesi TAC.

Mukadimah di dalam TAC menyatakan bahwa setiap pertikaian atau sengketa yang timbul antarnegara anggota ASEAN harus menghindari penggunaan kekerasan yang mungkin dapat membahayakan dan menghambat kerjasama di kawasan Asia Tenggara. TAC juga memuat tujuan dan prinsip-prinsip yang dianut dalam kerangka persahabatan dan kerjasama antarnegara anggota ASEAN. Tujuan dari TAC sebagaimana yang tercantum dalam bab I Pasal 1 yang menyatakan bahwa untuk mempromosikan perdamaian secara terus menerus, menjalin persahabatan serta kerjasama yang baik di antara negara anggota-anggota ASEAN.

TAC yang ditandatangani pada pertemuan puncak ASEAN pertama di Bali, pada tanggal 24 Februari 1976 sering disebut sebagai wujud dari nilai-nilai global yang mendasari pembentukan organisasi regional. Dalam pertemuan di Bali tersebut, negara-negara ASEAN sepakat untuk (Bambang Cipto, 2007):

a) Saling menghormati kemedekaan, kedaulatan, dan intergritas wilayah semua bangsa;

b) Setiap negara berhak memelihara keberadaanya dari campur tangan, subversi, kekerasan dari kekuatan luar;

c) Tidak mencampuri urusan dalam negara lain;

d) Menyelesaikan perbedaan pendapat dan pertikaian dengan jalan damai;

e) Menolak ancaman penggunaan kekerasan.

Apabila dilihat antara pembukaan dan ketentuanketentuan mengenai tujuan dan prinsip-prinsip dasar yang dianut maka salah satu isu yang diutamakan dalam perjanjian TAC ini adalah mengenai penyelesaian pertikaian atau sengketa yang 
terjadi antarnegara anggotaanggota ASEAN agar dilakukan dengan cara-cara damai tanpa menggunakan kekerasan atau perang untuk menjaga persahabatan dan kerjasama yang sudah terjalin. Pada bab IV dalam TAC mengatur mengenai penyelesaian sengketa secara damai yang terdiri dari 5 (lima) pasal, yakni Pasal 13-17. Berdasarkan bab IV TAC, terdapat 3 (tiga) mekanisme atau prosedur penyelesaian sengketa yang dikenal negaranegara anggota ASEAN, yang meliputi : penghindaran timbulnya sengketa dan penyelesaian melalui negosiasi secara langsung, penyelesaian sengketa melalui the High Council, dan cara-cara

\section{Daftar Pustaka}

Adolf, Huala, 2006, Hukum Penyelesaian Sengketa Internasional, Sinar Grafika, Jakarta.

Andrea, Faustinus, 2006, Perimbangan Kekuatan di Myanmar Faktor ASEAN dan Kepentingan Indonesia, Volume. 35 No. 2 Juni 2006, Analisis Centre for Strategic and International Studies (CSIS), Jakarta, hlm. 183

Brierly, J. L, 1996, Hukum BangsaBangsa Suatu Pengantar Hukum Internasional, Bharatara, Jakarta.

Cipto, Bambang, 2007, Hubungan Internasional di Asia Tenggara, Teropong Terhadap Dinamika, Realitas, dan Masa Depan, Pustaka Pelajar, Yogyakarta, hlm. 23

Dian Saraswati, A.A.S.P., 2007, Simplikasi Pengaruh Pelaksanaan Putusan penyelesaian sengketa berdasarkan Pasal 33 ayat (1) Piagam PBB.

\section{Simpulan}

TAC merupakan suatu kerangka hukum dalam tubuh ASEAN dalam menyelesaikan sengketa secara damai antara anggota-anggota ASEAN yang sedang bertikai maupun anggotaanggota ASEAN dengan negara lain yang bukan negara anggota ASEAN. TAC sangat mengedepankan penyelesaian sengketa secara damai dan sangat melarang menggunakan kekerasan di dalam menyelesaian sengketa yang tengah dihadapi oleh anggota ASEAN hal ini tidak lepas dari Pasal 33 ayat (1) Piagam PBB.

Mahkamah Internasional Dalam Memperluas Wilayah Laut Suatu Negara (Studi Kasus Sengketa Wilayah Ambalat Antara Indonesia Dengan Malaysia), Tesis Program Studi Ilmu Hukum Jurusan Ilmu-Ilmu Sosial, Program Pascasarjana UGM, Yogyakarta.

Direktorat Jenderal Kerjasama ASEAN Departemen Luar Negeri Republik Indonesia, 2007, ASEAN Selayang Pandang, Departemen Luar Negeri Republik Indonesia, Jakarta, hlm. 4

Ilien Halina, 1988, ASEAN, Pusat Antar Universitas (PAU), Studi Sosial Asia Tenggara (PSSAT), Universitas Gadjah Mada, Yogyakarta, hlm. 9

Mauna, Boer, Hukum Internasional; Pengertian, Peranan dan Fungsi Dalam Era Dinamika Global, PT. Alumni, Bandung, hlm. 193 
Merrills, John G, 1991, International Dispute Settlement, Cambridge : Cambridge University Press. Peneterjemah Achmad Fausan, Penyelesaian Sengketa Internasional, Tarsito, Bandung.

Ranjit Gill, 1987, ASEAN, PT. Gramedia, Jakarta, hlm. 12

Starke, J. G, 2007, Pengantar Hukum Internasional (edisi kesepuluh, Buku 1), Penerjemah Bambang
Iriana Djajaatmadja, PT. Sinar Grafika, Jakarta.

Sugeng Istanto, F, 1998, Hukum Internasional, Universitas Atma Jaya, Yogyakarta.

Thomas, Walter R, 1980, Pacific Blokade, A Lost Opportunity of the 1930's, dalam US Naval War College International Law Studies. 